\begin{tabular}{|c|ccc|c|}
\hline & PORT SAID ENGINEERING RESEARCH JOURNAL \\
\hline
\end{tabular}

\title{
Studying of Shear Walls with Piled Raft over Soft Soil against Seismic Loads
}

\begin{abstract}
W. H. El Kamash ${ }^{1}$, M. M. El Gendy ${ }^{2}$, R. W. Salib ${ }^{3}$, M. A. Kandil ${ }^{4}$

Modelling the interaction between piled raft and shear wall frame structure has not attracted many researchers in last decades. Herein, a 3-D continuum model of piled raft and shear wall frame structure was introduced. That model was incorporated into developed software in order to study the behaviour of shear wall against earthquakes. The soft soil type of Port-Said was examined in this study to get practical solutions for soft soil problem in such cases. Different parametric cases were presented to reflect the effect of the position as well as stiffness of shear walls on deformations, stresses, and moments and drift ratios. Factors were considered of shear wall geometry and stiffness to study the behaviour of shear walls with piled raft over soft soil. Soil was simu lated by elastic plastic model, while FEM was used to model piled raft and shear walls. ASTN3 which was developed by the author was used here to analyze different cases and numerical results and conclusions were introduced.
\end{abstract}

Keywords: soft soil, shear walls, piled raft, numerical analy sis, seismic loads, finite element method.

\section{INTRODUCTION}

Shear walls played an important role in resisting seismic loads which may cause severe damage for people or structures as shown in Figure 1. Kandilet al. (2013) presented a study of shear walls resting on piled raft against earthquake forces. That study was extended to include factors of piles' lengths and diameters and rig idity of the raft. Jahanpour et.al. (2012) studied an experimental study in order to investigate the failure behavior of the wall-plate and the frame which surrounds it. Results reflected the effect of cyclic load to perform tension stresses in the plate more than the surrounding frame. Different kinds of pre-fabricated concrete frames together with pre-fabricated multi-storey shear walls with different bays were presented by Majid and Morteza (2011). They employed non-linear static analysis method (Push-over) to examine the behavior factor of designing seismic loads. They employed nonlinear static analysis method (Push-over) to examine the behavior factor of designing seismic loads. Kim et al. (2005) developed an approach for analyzing shear wall with openings using super elements. Akis (2004) modeled the non-planar shear wall assemblies of shear wall-frame structures. He analyzed two and three dimensional models, for open and closed section shear wall assemblies, were developed. Many approaches of shear wall modeling such as wide column model, plane stress plate model, finite element model (FEM) and modeling with membrane element were presented by Vasanwala et al. (2010). Based on Finite difference technique with MATLAB code, Phanikanthet. al. (2010) examined single piles and pile groups against

\footnotetext{
${ }^{T}$ Dept. of civil Engineering, Port-Said University, Egypt, waleed_el_kamash@hotmail.com

2 Dept. of civil Engineering, Port-Said University, Egypt, melgendy@elpla.com

${ }^{3}$ Dept. of civil Engineering, Suez Canal University, Egypt, dr_rafeekws@hotmail.com

${ }^{4}$ M.Sc. Candidate, Department of civil engineering, Sinai University, Egypt,manhalkandil@yahoo.com
}

earthquake. Some of researchers modeled piled raft against both lateral and gravity loads. Paknahadet al. (2007) performed shear wall structure using optimal membrane triangle element. Ta and Small (1996) and Small and Zhang (2002) presented the piled raft in layered soils with a finite layer method, where Bajad and Sahu (2008) has examined the influence of interaction between piles and the raft. Huang et al. (2011) introduced a nonlinear solution for layered soil. Russo (1998) performed analytical approach using Boussinesq's solution. A numerical model based on Mindlin's solution was presented by Kitiyodom and Matsumoto (2003).That case of soil is a challenge against seismic loads in order to optimize deformations and internal forces. The objective of this study is to investigate the effect of using different shapes of shear wall-frame systems with piled raft foundation against earthquake excitations over Port-Said soil.The soft soil was examined here as case study of the soil. Particular attention was given to the settlements, horizontal displacements, and moments

\section{MATHEMATICAL MODEL}

A new version of ASTN2 named ASTN3 (analysis of structures resting on nonlinear soil) was developed by El Kamash et.al. (2012) to be capable to model shear wall as plane stress elements using Lattice Analogy. A square framework pattern can be used for the solution of twodimensional stress problem as shown in Figure 3. Values of areas of equivalent bars $A_{1}$ and $A_{2}$ which were used in the computation may be determined from the following equations based on Hrennikof (1949).

$$
\begin{aligned}
& A_{1}=\frac{3}{4} a^{\prime /} h(1) \\
& A_{2}=\frac{3}{4 \sqrt{2}} a^{\prime \prime} h(2)
\end{aligned}
$$


Here, piles, beams and columns are presented by frame elements, while the raft and slabs are presented as plate

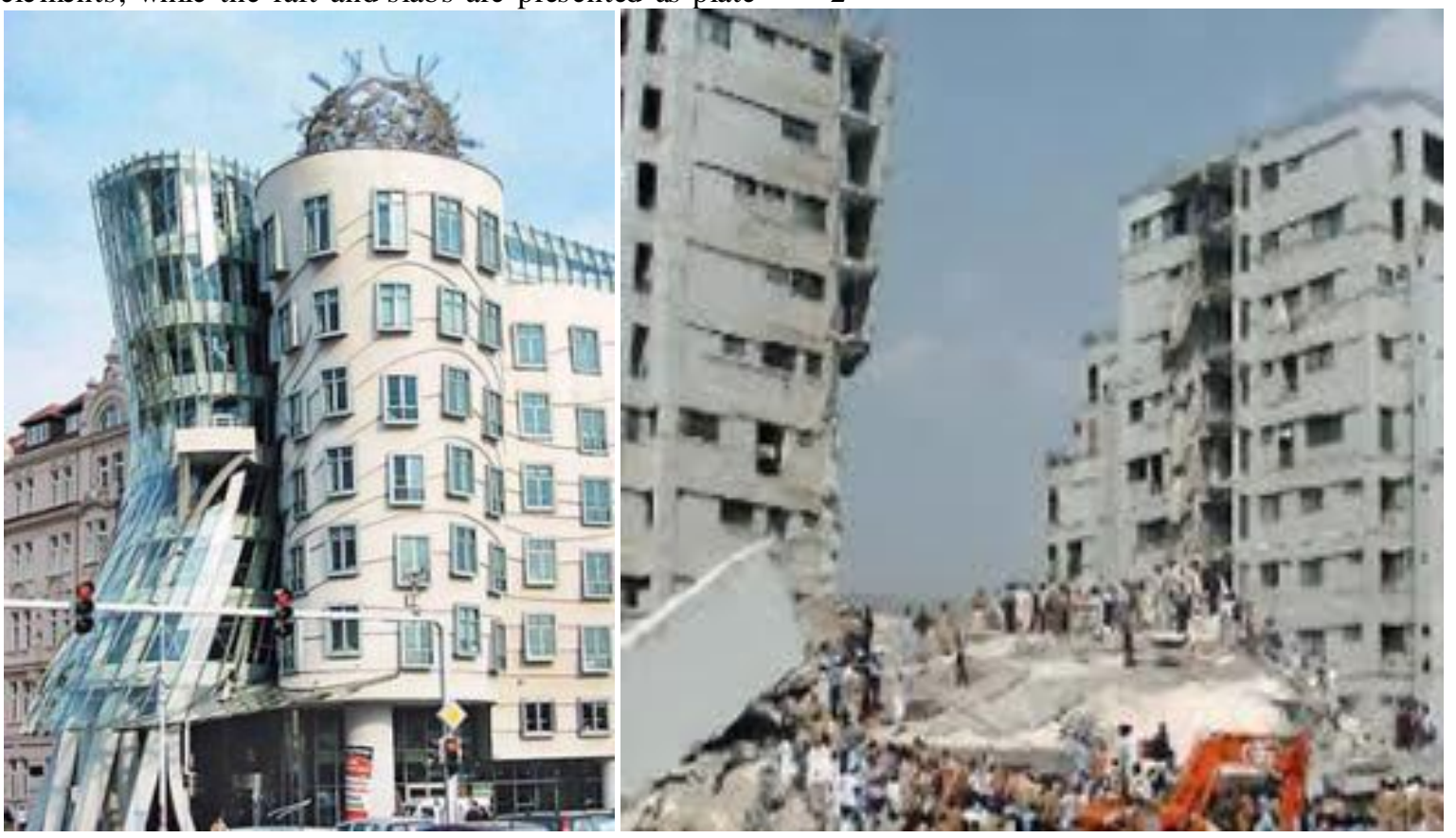

Figure. 1.Devastating effects to structures due to the earthquake in Egypt.

2. Based on Finite Element method, the raft can be expressed as an elastic plate on rigid piles as follows:

$$
\left[k_{e}\right]\{w\}=\{P\}-\{Q\}
$$

where:

$$
\begin{aligned}
& \text { : Plate stiffness matrix with number of rows } \\
& \text { and columns } n_{\mathrm{r}}^{*} \mathrm{n}_{\mathrm{r}} \text {. } \\
& \text { : Deformation vector of the raft with number } \\
& \text { of rows } 3^{*} \mathrm{n}_{\mathrm{r}} \text {. } \\
& \text { : Vector of the applied loads with number of } \\
& \text { rows } 3^{*} \mathrm{n}_{\mathrm{r}} \text {. }
\end{aligned}
$$

The effect of pile shortening was taken in the account, the elastic coefficient of the pile $i$ in the elastic pile matrix $\left[C_{p}\right]$ was added to the flexibility coefficient of that pile in the flexible matrix $\left[f_{e}\right]$ as follows:

$$
\{w\}=\left[\left[f_{e}\right]+\left[C_{p}\right]\right]\{Q\}
$$

where: $[\mathrm{Cp}]$ is the elastic pile matrix.

The total stiffness matrix of piled raft $\left[k_{p}\right]$ with the effect of pile stiffness due to its elastic material can be investigated by inverting the total flexibility matrix $\left[\left[f_{e}\right]+\left[C_{p}\right]\right]$ to be expressed as Eq. 5 .

$$
\{Q\}=\left[k_{p}\right]\{w\}
$$

where $\left[k_{p}\right]$ is $n_{r} * n_{r}$ stiffness matrix of the piled raft with the effect of pile elastic material, $\left[k_{p}\right]=\left[\left[f_{e}\right]+\left[C_{p}\right]\right]^{-1}$.

The hyperbolic relation between pile load and settlement was employed here to simulate the elastic perfect plastic behavior of the soil. The initial tangent modulus of the hyperbolic relation may be obtained from the linear analysis as follows:

$$
k_{\text {linear }}={\frac{Q_{h_{\text {linear }}}}{w_{\text {linear }}}}_{(6)}
$$

Where, $Q_{\text {hlinear }}$ is the force on the pile load obtained from the linear analysis and $w_{\text {linear }}$ is the pile settlement obtained from the linear analysis. The pile stiffness may be modified based on hyperbolic equation as follows:

$$
k_{\text {equ } i}=\frac{1}{\frac{1}{k_{\text {linear }}}+\frac{w_{i}}{Q_{i}}} \text { (7) }
$$

Determination of lateral displacements of piles subjected to horizontal loads usually requires the use of an elastic continuum model of the soil as introduced by Poulos and Davis (1980). Piles were modeled to be thin rectangular vertical strips of width $d$, length $l p$, with constant flexibility. Possible horizontal shear stress developed between the soil and the sides of the pile were excluded. The soil was presented by a group of elements attached to each pile at discrete nodes. Elements whichwere distributed along the shaft represent the passive pressure of the soil. In this analysis, the super-sub structural elements were analyzed simultaneously against both vertical and lateral loads.

\section{Verification}

A 3D Fin ite Element method for Analysis of Structures resting on Nonlinear soil (ASTN) version 3 was developed in this study. ASTN3 software was used in this study in order to analyze different shapes of 3-D buildings over piled raft embedded in the soil. The response of each pile, slabs and the raft was modeled using continuum model, while the interaction among elements; pile-soil pile, raft-soil-raft and pile-soil-raft 
was calculated on the bases of integration of Mindlin's solutions. Herein, a verification example which was carried out by ASTN3 is presented; shear wall under lateral loading as illustrated in the following section.

The proposed model which is shown in Figure 4 was examined to present a comparison between results of shear wall model analy zed by ASTN3 with those carried out by other methods. The verification example is consisted of three bays and ten storeys plane frame with considering a center shear wall of the width of the bay. The cross section of columns and beams is $0.3 \mathrm{~m} * 0.3$ $\mathrm{m}$, while, it is $0.15 \mathrm{~m} * 3.0 \mathrm{~m}$ for the shear wall. A 100 $\mathrm{kN}$ horizontal load was applied at the top left of the

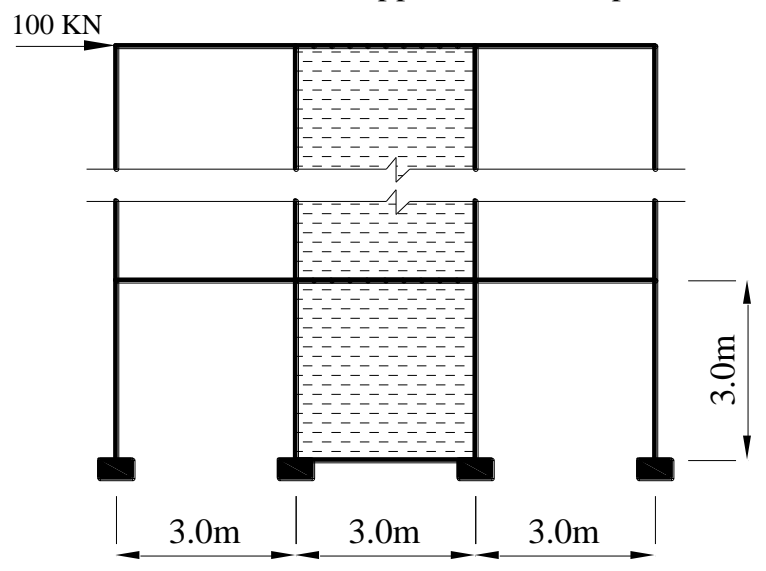

Figure. 4. The model of the verification example frame. The interaction of frame elements with the shear wall is also considered. The shear wall was modeled using different methods; Wide Column, Plane Stress Plate Element, Finite Element Meshing and a Membrane Element as presented by Vasanwala et al. (2010), in addition to ASTN3 which is used to analyze that structure also. Results were illustrated in Figure 5 and Table 1 to achieve the comparison between results of different numerical analysis and ASTN3. It can be noted that, there is a reasonably well agreement between results which were computed by the proposed model in this study ASTN3 and those obtained from other models.

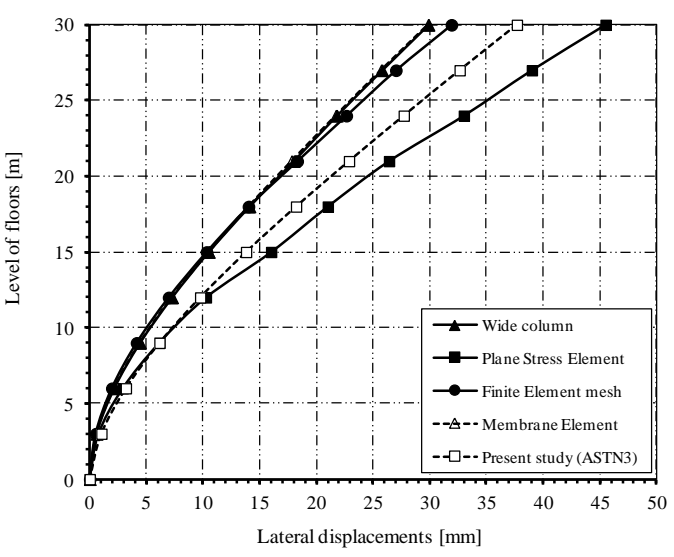

Figure. 5. Comparis on of deflections

Table 1 Forces in the lower panel of the shear wall and top storey's sway in 10 -storey model

\begin{tabular}{|c|c|c|c|c|}
\hline Method of analysis & $\begin{array}{c}\text { Top Storey's } \\
\text { Sway }(\mathrm{mm})\end{array}$ & Axial Force $(\mathrm{kN})$ & Shearing Force $(\mathrm{kN})$ & Moment (kN.m) \\
\hline Wide Colu mn & 29.89 & 416.74 & 95.33 & $1,138.66$ \\
\hline Membrane & 29.84 & 392.54 & 95.59 & $1,143.48$ \\
\hline Fin ite Mesh & 31.93 & 378.83 & 96.34 & $1,136.49$ \\
\hline Plane Stress Plate & 45.53 & 416.34 & 95.17 & $1,249.03$ \\
\hline Present study (ASTN3) & 37.68 & 367 & 98.95 & $1,101.00$ \\
\hline
\end{tabular}

Results of pile group which have been analyzed by ASTN3 which is used in this study showed a good agreement with other computer programs such as PIGLET, GEPAN and PGROUPN.

\section{Parametric study}

\subsection{Description, geometry and properties of models} In this study, 3D-12 storey-space structure of rectangular typical floors models with piled rafts resting on nonhomogeneous soil medium were analyzed nonlinearly

considering the soil-structure interaction. The rectangular structure has three bays in $X$-direction and six bays in $Y$-direction as shown in Fig. 7. In all cases,

the height of ground and typical floors are $4.0 \mathrm{~m}$ and $3.0 \mathrm{~m}$, respectively. The structural system of all roofs is a flat slab type of $20 \mathrm{~cm}$ thickness subjected to a total uniform load of $10 \mathrm{kN} / \mathrm{m}^{2}$. Dimensions of columns and shear walls are listed in table 2 . The foundation of each model is a piled raft type as shown in Fig.8. The raft was assumed to be at a depth $2.0 \mathrm{~m}$ beneath the ground surface and has $1.25 \mathrm{~m}$ thickness. The estimated total vertical load on both square and rectangular rafts is 101.265 MN. The structure is exposed to seismic loads due to a ground acceleration $a_{g}=0.15 \mathrm{~g} \mathrm{~m} / \mathrm{s}^{2}$ with fundamental natural period $T_{1}=1.3 \mathrm{sec}$., where $g$ is the gravity acceleration. In the analysis, Finite Element method was employed to model the raft and flat slabs of typical and ground floors' roofs by plate element, while rigid frame elements represented piles. The shear wall was represented based on Lattice Analogy. The interaction between different elements was taken in the consideration. The effective depth of the soil layers under the raft was supposed to be $50 \mathrm{~m}$. Source data of the soil was investigated based upon the extensive 
geotechnical study performed by Golder Associates (1979) andReda(2009). The clay extends to an average depth of about $50 \mathrm{~m}$ below the ground surface, the clay resting on basal deposits of very hard clay and dense sand. The velocity of shear waves is considered $\mathrm{V}_{\mathrm{S}, 30}=$ $156 \mathrm{~m} / \mathrm{s}$. Mossad (1996) stated that the soil which has number of S.P.T. over 15 can be considered as nonliquefied soil. So that, the only filling layer with depth of $2.0 \mathrm{~m}$ of Port-Said soil is excluded from the present analysis.

Slabs, columns and raft haveYoung's modulus $E=3.4 *$ $10^{7} \mathrm{kN} / \mathrm{m}^{2}$, Poisson's ratio $v=0.2$ and Unit weight $\gamma=$ $25 \mathrm{kN} / \mathrm{m}^{3}$, while modulus of elasticity was $E=2.35 *$ $10^{7} \mathrm{kN} / \mathrm{m}^{2}$ for piles.

Table 2Dimensions of columns and shear walls of the models under studying

\begin{tabular}{|c|c|c|c|c|}
\hline \multirow{2}{*}{ Dimensions (m) } & $\mathbf{C}_{1}$ & $\mathbf{C}_{2}$ & $\mathbf{C}_{\mathbf{3}}$ & Shear wall thickness \\
\cline { 2 - 5 } & $0.5^{*} 0.5$ & $0.6^{*} 0.6$ & $0.7 * 0.7$ & 0.2 \\
\hline
\end{tabular}

Here in, the base case was considered with exterior shear wall with thickness of $20 \mathrm{~cm}$; case 1 as shown in Fig. 8(b). Cases were considered for different positions of shear wall from the base case; cases 2 and 3 as shown in Figs. 8(c) and (d) respectively in addition to case of columns only as shown in Fig. 8(a). Also, cases of different thicknesses of shear wall; 20,30 and $40 \mathrm{~cm}$ fro $m$ the base case were considered.

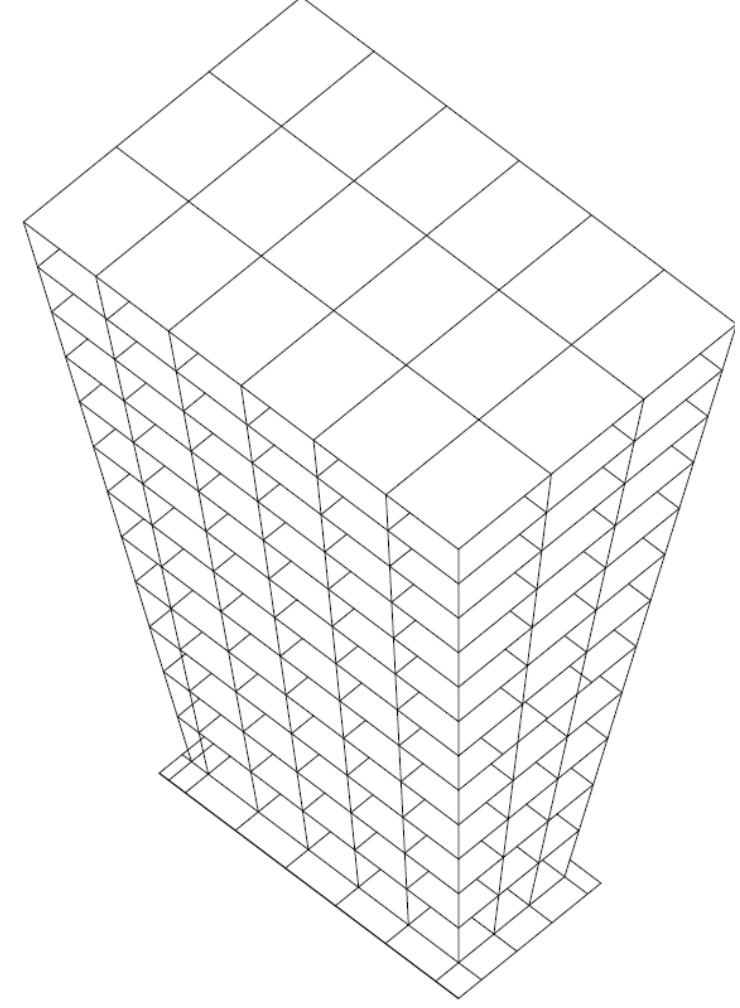

Figure.6.3D-12 storey-space structure of the models under studying 


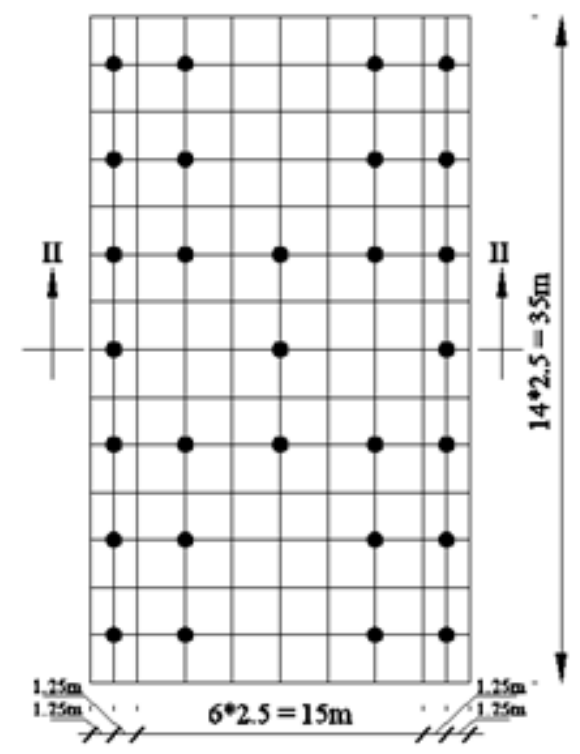

Figure.7.Distribution of piles in the piled raft

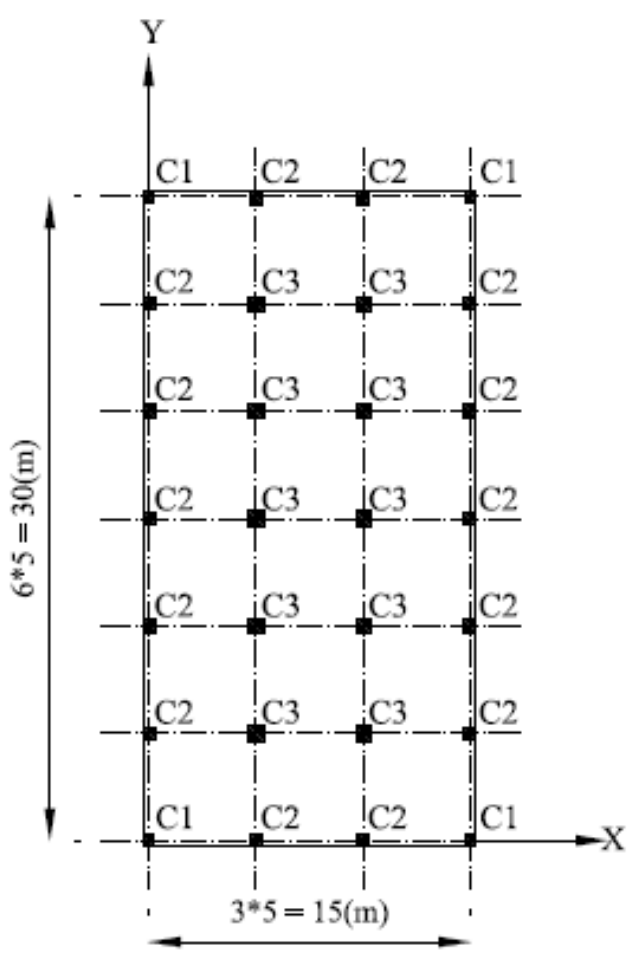

(a) Columns without shear walls

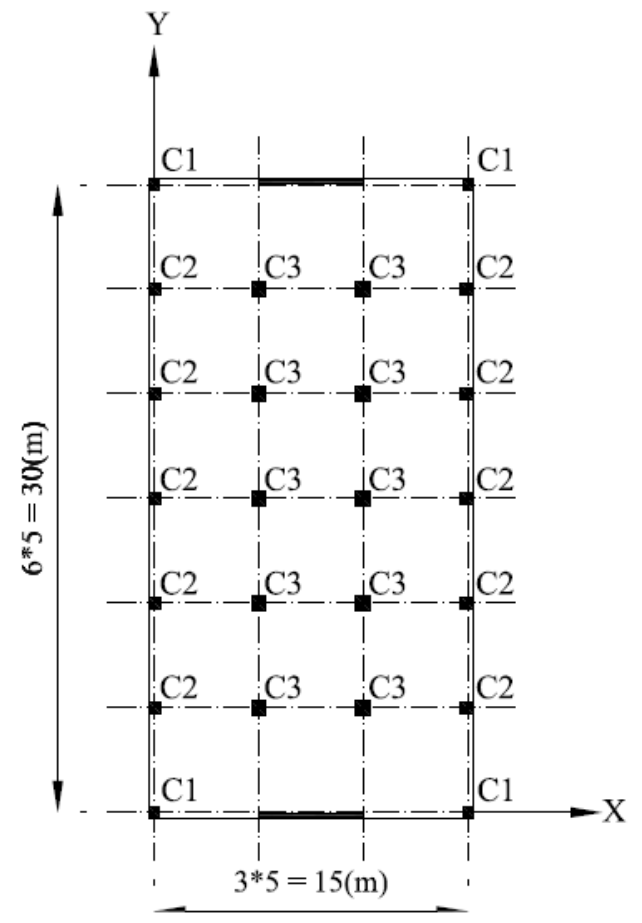

(b) Columns and shear wall (case I) 

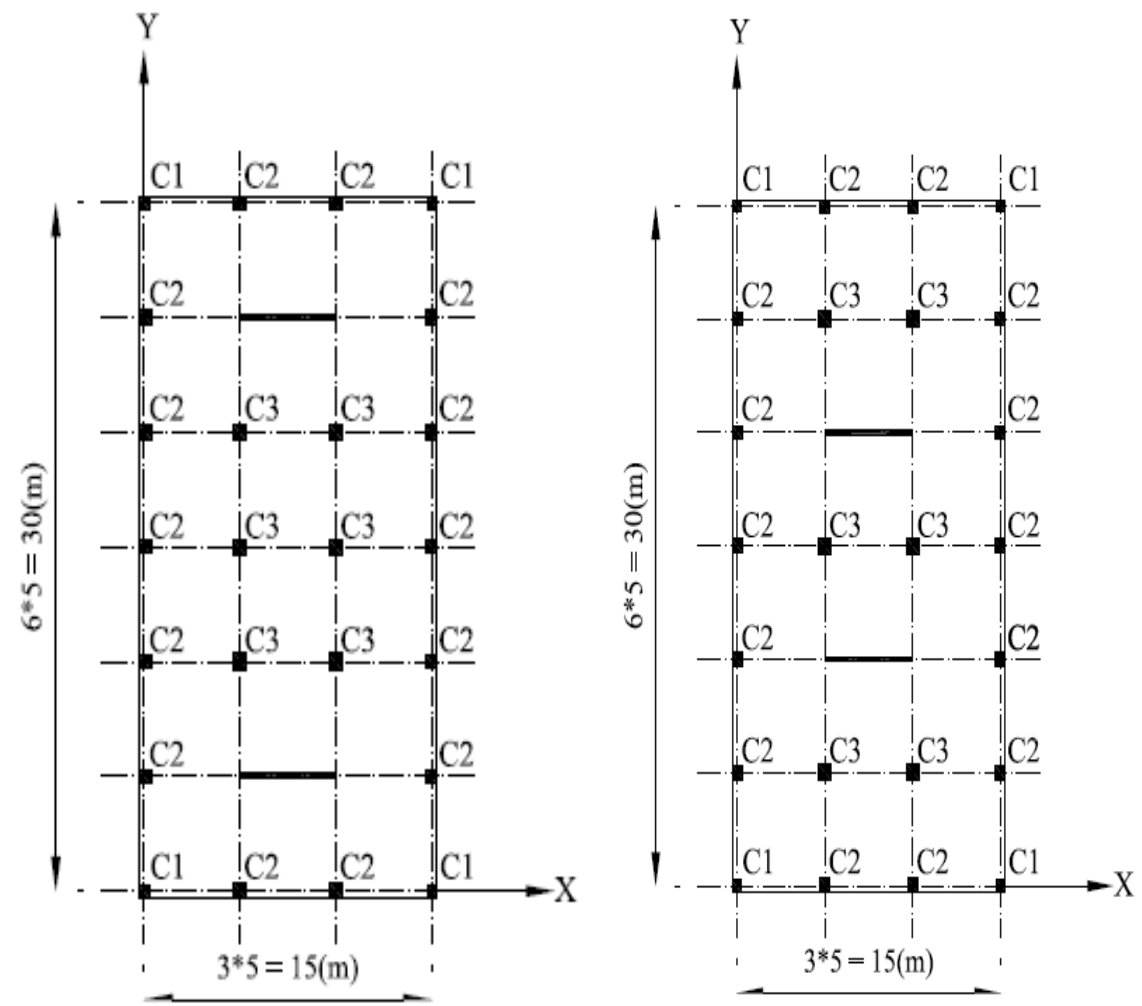

(c) Colu mns and shear wall (case II) (d) Colu mns and shear wall (case III)

Figure.8. Cases of rectangular model

\subsection{Settlement}

Figures 9 (a) and (b) show the settlement profile at Sec. II-II for different case of positions and thicknesses of shear wall. Lateral forces produced by the earthquake affected on settlement profile. Those forces increased settlement beneath the raft in the opposite side of the seismic forces. The Transverse gradient change which is defined as the distortion (i.e., different settlement /distance) reached to $0.26 \%$ in the case of columns only. That transverse gradient was reduced by $10 \%$ due to presence of shear walls case1 as shown in Fig. 9(a). That reduction reached to a percentage of $13 \%$ due to the increment of shear wall thickness (case of thickness 40 $\mathrm{cm})$ as shown in Fig. 9(b). The change of the position of shear walls does not affect on settlement as shown in Fig. 9(a). Also, the increment of the thickness of shear walls has not a significant effect on settlements as shown in Fig. 9(b). That means that playing of superstructure factor has a small influence of deformations under the foundation.
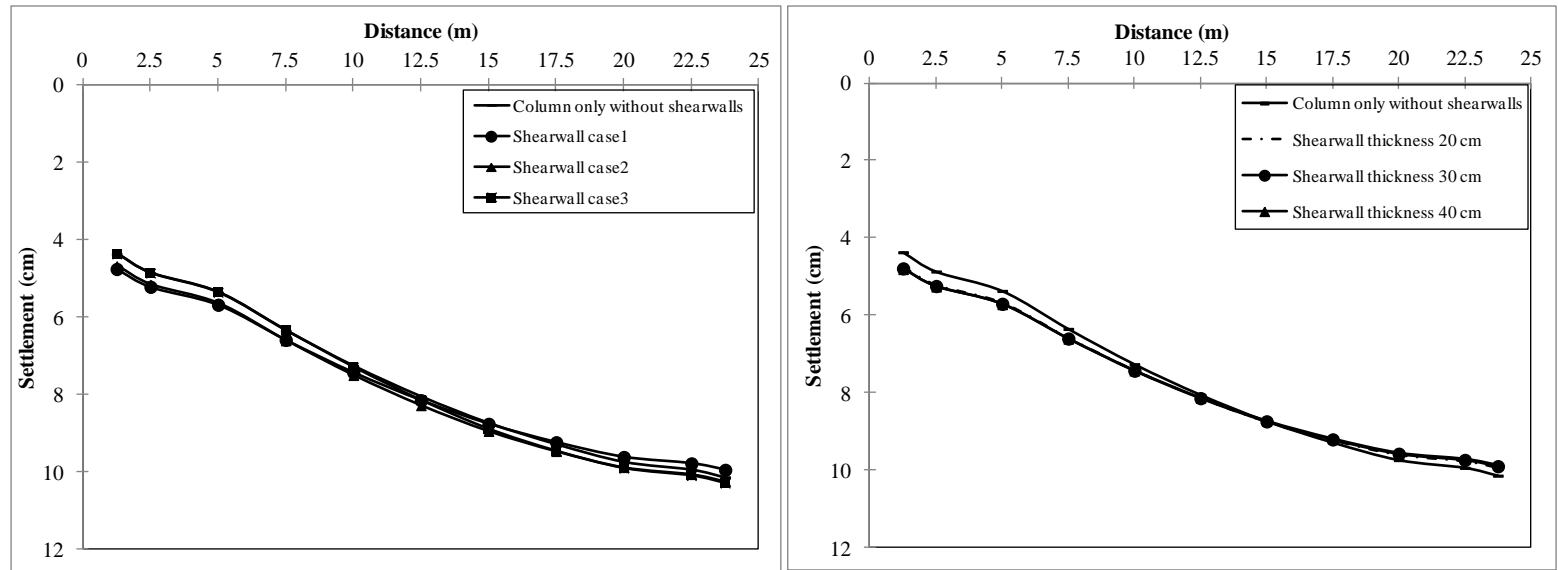

(a) Different cases of shear wall positions

Figure. 9. Settle ment profile

\subsection{Contact pressure}

Figures 10(a) and (b) show the contact pressure profile at Sec. II-II of the piled raft for different cases of shear (b) Different cases of shear wall thic knesses

walls' positions and thicknesses. Due to the rigidity of the foundation, the contact pressure increases at edges on the account of the middle part. Values of the contact of pressure at the other side of the earthquake direction are 
greater than those at the other edge. That behavior is similar to settlement one due to seismic force. Case 1 of shear wall reduced maximu $m$ values of contact pressures by $6 \%$, while it increased minimu $m$ values by $16 \%$ at the case of column only as shown in Fig. 10(a). The increment of the thickness of shear wall decreased the maximu $m$ values of the contact pressure by $12 \%$ at case (40 cm thickness) compared to the case of $(20 \mathrm{~cm}$ thickness) as shown in Fig. 10(b).

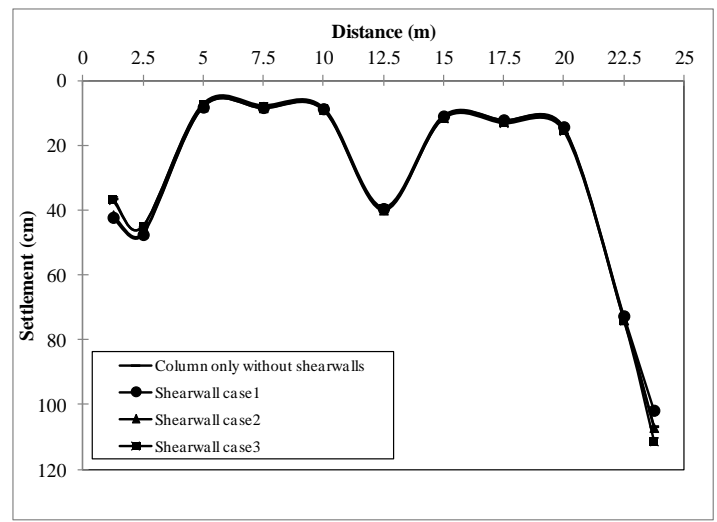

(a) Different cases of shear wall positions

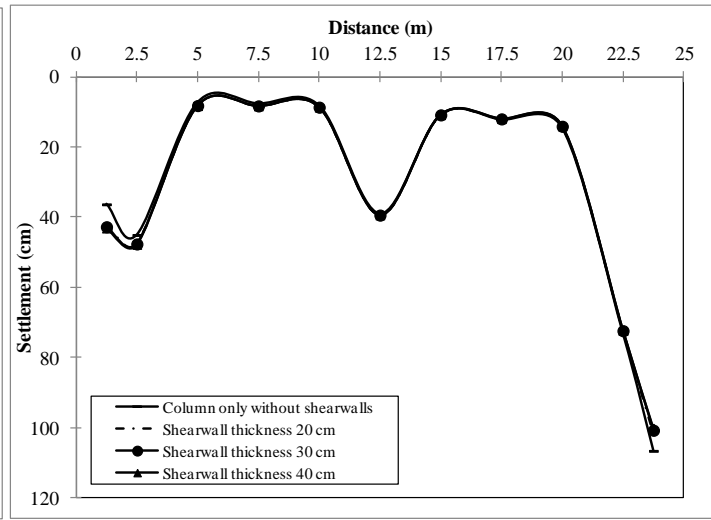

(b) Different cases of shear wall thicknesses

Figure. 10. Contact pressure profile

\subsection{Lateral Displacement}

Figs. 11(a) and (b) show the maximum lateral displacements due to different cases of shear walls' positions and thicknesses respectively. It is obviously noted that shear wall (case1) decrease lateral displacements by about $15 \%$ of those at case of columns

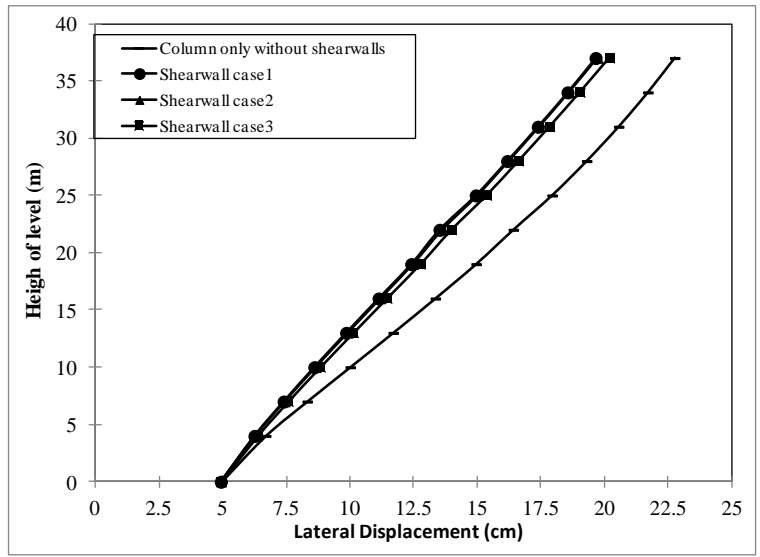

only as shown in Fig. 11(a). A slight reduction was happened due to increment the thickness of the shear wall from 20 to $40 \mathrm{~cm}$ which is not more than $6 \%$ as shown in Fig. 11(b). That means that the playing of the factor of shear wall position is more effective than the thickness on controlling lateral displacements.

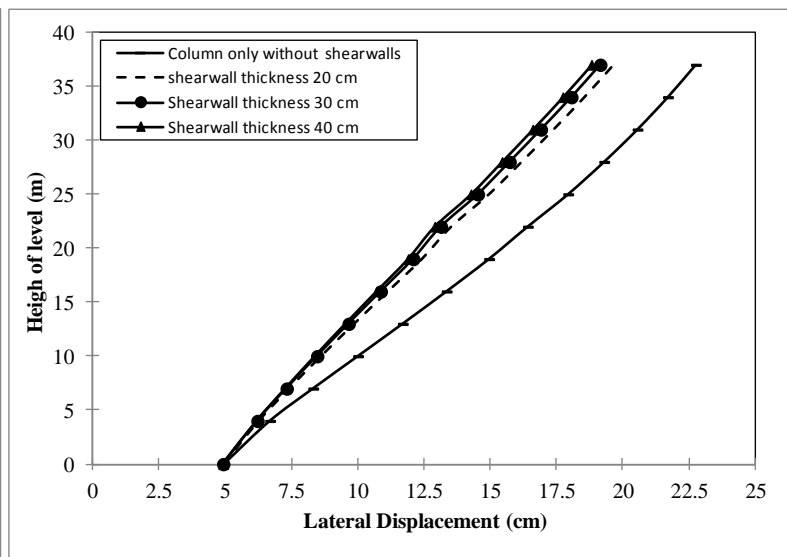

(a) Different cases of shear wall positions

(b) Different cases of shear wall thicknesses

Figure. 11. Lateral displacement against height of floors

\subsection{Drift ratio}

Egyptian code considers the value of $1 \%$ of drift ratio is the maximum limit for values of drift ratio. So that, the factor of safety can be considered as the inverted value of the drift ratio. Figures 12(a) and (b) show that the different cases of change the shear walls' positions and thicknesses respectively. The presence of the shear wall reduced the maximum drift ratio by $26 \%$ compared to case of column only regardless the case of the position as shown in Fig. 12(a). The reduction of the maximum drift ratio due to the increment of the thickness of the shear wall is not more than $10 \%$ compared to case (thickness $=20 \mathrm{~cm}$ ) as shown in Fig. 12(b). 


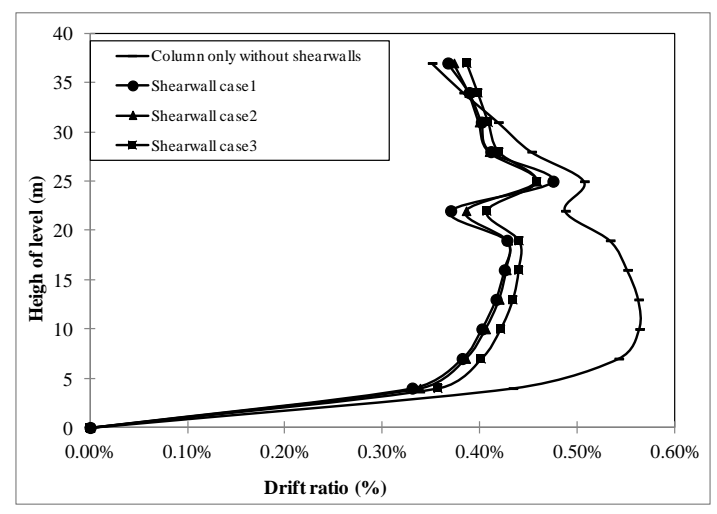

(a)Different cases of shear wall positions

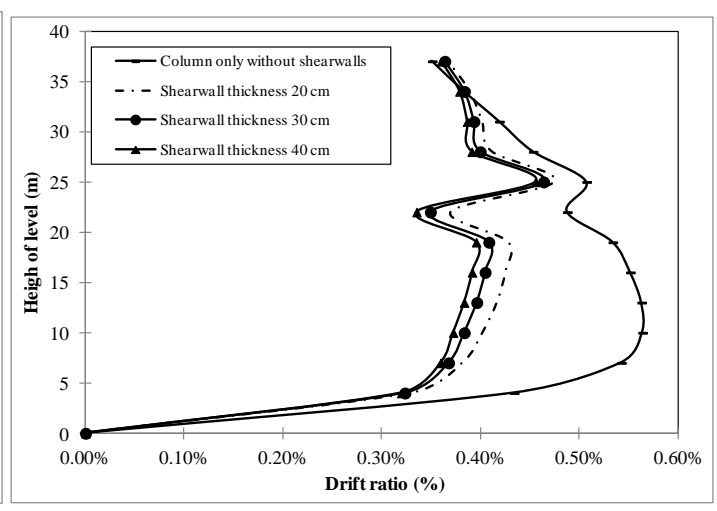

(b) Different cases of shear wall thicknesses

Figure. 12. Drift ratios against height of floors

\subsection{Moment in the raft at Sec. II-II}

Figures 13(a) and (b) show that the different cases of change the shear walls' positions and thicknesses respectively. As the position of shear walls moves to inside, maximum moments increase at Sec. II-II. That increment reached to percentage of $34 \%$ at case 3 compared to case1 as shown in Fig. 13(a). The increment of thickness of shear walls has not any significant effect on bending moments as shown in Fig. 13(b).
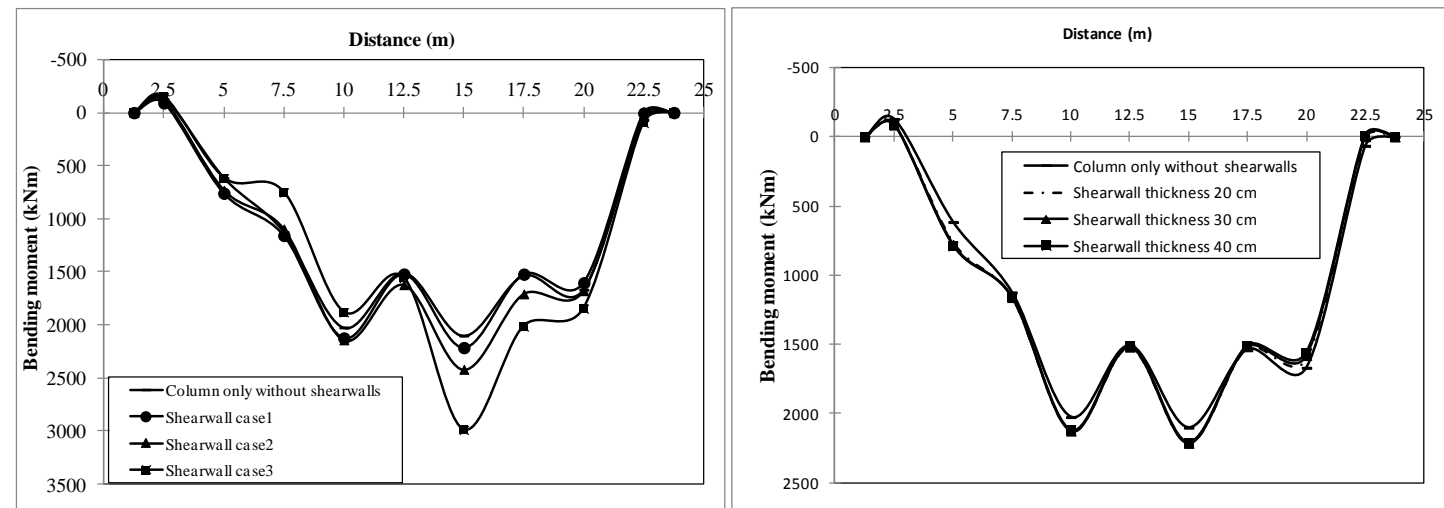

(a) Different cases of shear wall positions (b) Different cases of shear wall thickness es

Figure. 13.Bending moment profile at Sec. II-II

\section{Conclusions}

A program code ASTN3 was developed to analyze 3D shear wall problems resting on piled raft. Verification was performed by comparing results obtained from ASTN3 and those obtained from published cases. A parametric study was analyzed as 3D shear walls structure with piled raft resting on Port-Said soil medium under gravity and earthquake loads.Different positionsand thicknesses of shear walls were examined. Results were focused on deformations, vertical stresses and moments in the soil beneath the foundation.By changing positions of shear walls, it is found that the position of exterior shear walls is the best case to control lateral displacements, contact pressures and moments in the soil beneath the piled raft foundation compared to other cases shear walls' positions. The increment of thicknesses of shear walls has relatively a small effect on reducing deformations, vertical stresses and moments. Moving the position of shear walls to the interior position increased the maximum moments by $42 \%$, while the change of the thickness was not effective. However, the presence of shear walls has a strong effect to increase the factor of safety from 1.8 to 2.4 . Results showed that both the change of shear walls' positions and thicknesses have a little effect on reducing settlements.

\section{References}

Akis, T.(2004) Lateral load analysis of shear wall-frame structures, Ph.D. Thesis, Middle East Technical University, Turkey.

Bajad, S. and Sahu R. (2008) An Experimental Study on the Behaviour of Vertically Loaded Piled Raft on Soft Clay. The 12th International Conference of International Association for Co mputer Methods and Advances in Geomechanics (IA CMA G) 1-6 October, Goa, India

Divan, M. and Madhkhan, M. (2011) Determination of behavior coefficient of prefabricated concrete frame with Prefabricated Shear Walls. Elsiever, j.proeng, Vol14, pp 3229-3236

El-kamash, W. (2009). Analys is of 3D-structures resting on piled raft, Ph.D. Thesis, Suez Canal University, Egypt. 
El Kamash, W., El Gendy M, Salib R. and Kandil M. (2012) Analysis of shear walls on piled raft under earthquake exc itations, conference 2012CSCE

Canadian society of Civil Engineering, Ed monton, Canada.

Golder Associates 1979. Geotechnical report for portsaid area. Port-Said, Egypt.

Hrennikoff, A. (1949). Framework method and its technique for solving plane stress problems. Publ. Intern. Assoc. BridgeStruct. Eng., Vol. 9,pp.217247.

Huang, M., Liang, F. and Jie, J. (2011) A simplified nonlinear analys is method for piled raft foundation in layered soils under vertical loading. J. Computers and Geotechnics, Vol. 38, pp. 875882

Jahanpour, A., Jönss son, J. and Moharrami, H. (2012) Seis mic behavior of se mi-supported steel shear walls, Journal of Constructional steel research, Vol. 74, pp. 118-133.

Kandil, M, El Gendy, M, Salib Rafeek and El Kamash, W. (2013) "Behavior of structures with shear walls resting on piled rafts in Port Said", M.Sc.Thesis, Suez Canal University, Egypt.

Kim, H., Lee, D. and Kim, C. (2005) Efficient threedimensional seismic analys is of a high-rise building structure with shear walls, $J$. Engineering Structures, Vol. 27, pp. 963-976.

Kitiyodom, P. and Matsumoto, T.(2003) A Simplified Analysis Method for Piled Raft Foundations in Non-homogeneous Soils, Int Jl. for Numerical and Analytical Methodsin Geomechanics, Vol. 27, No. 2, pp. 88-109.
Mossad, M. (1996)Liquefaction during the October 12, 1992 Dahshour, Egypt, earthquake and its potential in the Nile Valley and Delta",J. Soils and foundations, Vol.36, No. 2, pp. 13-27.

Paknahad, M., Noorzaei, J., Jaafar, M. and Waleed, A. (2007) analysis of shearwall structure using optimal me mbrane triangle element, J. Finite Elements in Analysis and Design, Vol. (43), pp. 861-869.

Phanikanth, V., Choudhury, D. and Reddy, G. (2010) Response of single pile under lateral loads in cohesionless soils, ScienceDirect, J. Computers and Geotechnicsl,Vol. (15), pp. 813-830

Poulos, H. and Davis, H.(1980) Pile Foundation

Analysis and Design, Jhon Wiley \&Sons Inc., New York.

Reda, A. (2009) Optimization of piled raft in Port-Said, M. Sc. Thesis, Suez Canal University, Egypt.

Russo, G.(1998) Numerical analysis of piled rafts, Int $J l$. for Numerical and Analytical Methods in Geomechanics, Vol. 22, No. 6, pp. 477-493.

Small J., Zhang H. (2002) Behaviour of piled raft foundations under lateral and vertical loading. Int J Geomech, Vol. 2(1), pp.29-45.

Ta, L. and Small, J.(1996), "Analysis of Piled Raft Systems in Layered Soils", Int.Jl. for Numerical and Analytical Methods in Geomechanics, Vol. 20, pp. 57-72.

Vasanwala, S., Ku mar, K. and Thakkar, G (2010) Analytical modeling of rectangular RC shear walls, J. of Structural Engineering, Vol. 3(1), pp. $42-53$ 